\title{
Knowledge, Attitude and Practice towards the Corona Virus (COVID-19) Pandemic among the Pregnant Women
}

\author{
Supriya Rai ${ }^{1}$, Neetha Poonja ${ }^{2}$, Neetha Nandhan ${ }^{3}$, Sapna Chauhan ${ }^{4}$, Shruthi Alevoor ${ }^{5}$ \\ 1,2,3,4,5 Department of Obstetrics and Gynaecology, K S Hegde Medical Academy, \\ Mangaluru, Karnataka, India.
}

\section{ABSTRACT}

\section{BACKGROUND}

We intended to assess the knowledge, attitude and practice of preventive measures followed against Covid-19 infection among pregnant women attending the antenatal clinic at K S Hegde Medical Academy, Mangalore.

\section{METHODS}

This cross-sectional study was conducted among the pregnant women attending antenatal clinic at K S Hegde Medical Academy, Mangalore, from July $1^{\text {st }} 2020$ to August $31^{\text {st }}$ 2020. A validated questionnaire was provided to the patient. It consisted of 2 parts, demographic data, and 25 questions regarding knowledge, attitude, and practices.

\section{RESULTS}

Among 202 participants the overall knowledge, attitude and practice scores were $90.64 \%, 97.33 \%$ and $98.8 \%$ respectively.

\section{CONCLUSIONS}

Majority of pregnant women demonstrated good knowledge, positive attitude and good practice regarding Covid-19 pandemic.

\section{KEY WORDS}

Covid-19, Knowledge, Attitude, Practice, Pandemic, India
Corresponding Author: Dr. Neetha Poonja,

Flat No. 403, Haribhakthi Apts, Pintos Lane, Mangalore - 575004, Karnataka, India.

E-mail: neetpoonja@yahoo.co.in

DOI: $10.14260 /$ jemds/2021/255

How to Cite This Article:

Rai S, Poonja N, Nandhan $N$, et al. Knowledge, attitude and practice towards the corona virus (COVID - 19) pandemic among the pregnant women. J Evolution Med Dent Sci 2021; 10(17):1191-1196, DOI: $10.14260 /$ jemds/2021/255

Submission 17-11-2020,

Peer Review 24-02-2021,

Acceptance 03-03-2021,

Published 26-04-2021.

Copyright (C) 2021 Supriya Rai et al. This is an open access article distributed under Creative Commons Attribution License [Attribution 4.0 International (CC BY 4.0)] 


\section{BACKGROUND}

The novel coronavirus disease 2019 (Covid-19) caused by severe acute respiratory syndrome coronavirus 2 (SARSCoV-2) was diagnosed from Wuhan, Hubei Province (Mainland China). In reciprocation to the outbreak in China, World Health Organization (WHO) declared it as a public health emergency of international concern and called global imperative efforts to prevent the escalation..$^{1,2}$ As on October $20^{\text {th }} 2020$ over 41.6 million and 1.1 million deaths have been reported globally.

SARS-CoV- 2 is an enveloped RNA $\beta$ coronavirus with an outer fringe of envelope proteins resembling like crown. It has a phylogenetic genome similarity with highly pathogenic and transmissible well-known virus i.e. SARS-CoV-1 (2003) and MERS-CoV (2012).3, 4 Studies suggest the basic reproduction number (R0) of SARS-CoV-2 to be around 2.2 or may be up to 6 , making the virus propagate at a very high rate and proving to be very expeditious and erratic. ${ }^{5}$ It is found to be a zoonotic pathogen that transmits through respiratory droplet, physical contact and orofecal route. It has an incubation period of 2 - 14 days but infected persons can transmit the virus via close contact and respiratory droplets perhaps even before they become symptomatic. ${ }^{6}$

The disease appears to be particularly morbid in certain populations that include those older than 60 years of age, association of comorbidities and immunocompromised patients. ${ }^{5} 7$ Pregnant women are also considered to be a highrisk group because of the immune suppression caused by pregnancy. The immunologic and physiologic changes of pregnancy might make the pregnant women at a higher risk of severe illness with Covid-19, compared with the general population. In Middle East respiratory syndrome (MERS-CoV) and severe acute respiratory syndrome (SARS-CoV), the case fatality rate appeared higher in pregnant women. ${ }^{8}$ currently, more than 100 million women are pregnant worldwide and have a risk of contracting Covid-19. As per the morbidity and mortality weekly report of US Department of Health and Human Services / Centres for Disease Control and Prevention, pregnancy is associated with increased risk for ICU admission and receipt of mechanical ventilation, but it is not associated with increased risk of mortality. ${ }^{9}$ Some of the additional precautions that the pregnant women can take include not skipping antenatal care appointments, limiting interactions with other people as much as possible, taking precautions to prevent getting Covid-19 when interacting with others such as wearing masks, having at least a 30 -day supply of medicines and talking to their health care provider about how to stay healthy during the Covid-19 pandemic. ${ }^{9}$ To reduce Covid-19 associated illness, pregnant women should be aware of their potential risk of the severity and the effects of the infection on the mother and baby. Prevention of Covid19 should be emphasized for pregnant women and potential barriers to adherence to these measures need to be addressed.10,1

The symptoms of Covid-19 infection are mainly cough, sore throat and fever. Fever and hypoxemia may increase the risks of preterm labour, premature rupture of membranes and abnormal foetal heart rate patterns. ${ }^{11}$ The incidence of preterm deliveries also occur in patients without severe respiratory disease. Many of third-trimester cases are electively delivered by caesarean in intervene view of the bias faced to catalyse by the belief that management of severe maternal respiratory disease would be improved by delivery. However, this hypothesis is unproven. ${ }^{12}$ Hyperthermia which is common in Covid-19 is a concern as elevation of maternal core temperature from fever during organogenesis in the first trimester may be associated with an increased risk of congenital anomalies such as neural tube defects and miscarriage in first trimester. ${ }^{8}$ An increased incidence of these outcomes has not been observed. Use of acetaminophen in pregnancy in the first trimester has been shown overall to be safe and may decrease the pregnancy risks associated with fever exposure.7, 13

Person to person transmission is currently ongoing in the country making it necessary to control the disease. To guarantee successful disease control people's adherence to preventive and control measures are essential. This is highly dependent on the population's knowledge, attitude and practice (KAP) towards Covid-19 following the KAP theory.5,14 A previous study indicates that the knowledge level and attitude towards infectious diseases are associated with the level of panic among the population, which can further complicate attempt to prevent the spread of the disease. ${ }^{5}$

The purpose of the study was to evaluate the factors which influence the knowledge, attitudes and practices of pregnant women on preventive measures against Covid-19 and to also evaluate the association between the demographics and KAP of Covid-19.

\section{METHODS}

This was a cross-sectional survey conducted among pregnant women attending antenatal clinic at K S Hegde Medical Academy, Mangalore, after taking informed consent. The study was conducted for 2 months from July $1^{\text {st }} 2020$ to August 31st 2020. A validated questionnaire was used to collect the data. It consisted of demographic data and the questionnaire with questions regarding knowledge, attitude and practices. Information published in literature including publications available on WHO and the Centres for Disease Control and Prevention (CDC) were utilized at large. Participants with age more than 18 years who can understand the content of the survey and willing to participate were included. The questionnaire was prepared in English language and then translated to local language that was used for data collection. The questionnaire was then refined accordingly for final use.

The independent variables were demographic characteristics like age, address, education, occupation, gestational age, awareness about the pandemic and history of travel in the recent past, presence of co-morbid conditions like bronchial asthma, diabetes mellitus, hypertension, tuberculosis and cardiac diseases. The dependent variables were knowledge, attitude and practices towards prevention of Covid-19 infection. Questions on knowledge were about the spread of the virus, symptoms if contracted, visit to health care worker, safety of pregnancy during the pandemic and knowledge about the treatment. The questions on attitude were regarding social distancing, need for lockdown, changes in the diet, universal testing and anxiousness about getting infected by the virus. 


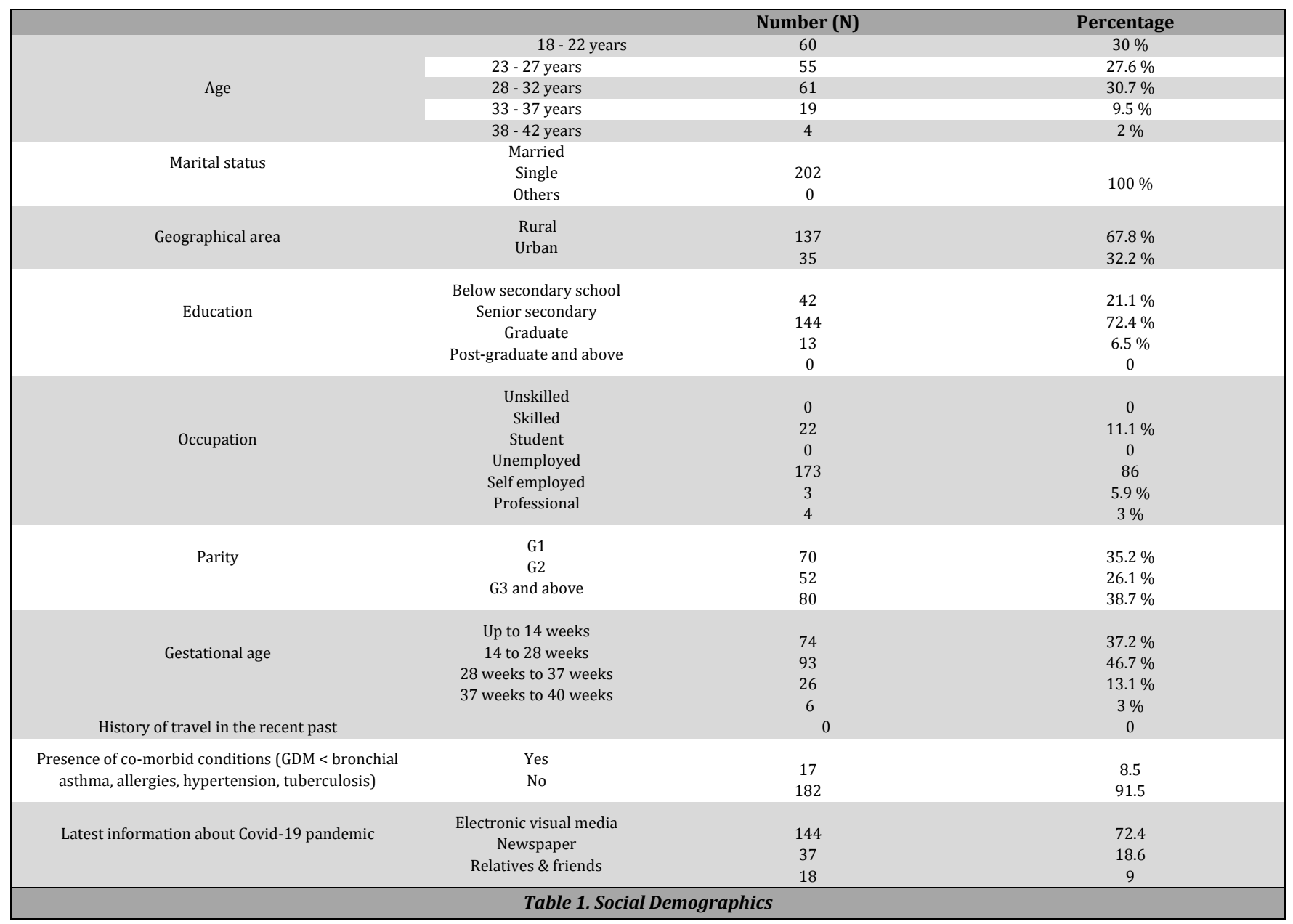

\begin{tabular}{|c|c|c|c|}
\hline Questions & & Numbers Answered & Percentage \\
\hline Are you aware of ongoing COVID - 19 infection pandemic? & $\begin{array}{l}\text { Yes } \\
\text { No } \\
\text { Don't know }\end{array}$ & (1) & 100 \\
\hline How do you think is the spread of COVID - 19 virus? & $\begin{array}{c}\text { Spreads via respiratory droplets of infected individuals. } \\
\text { Touching the infected surfaces } \\
\text { Through contact with infected individuals } \\
\text { None of the above } \\
\text { All of the above }\end{array}$ & $\begin{array}{c}77 \\
26 \\
53 \\
4 \\
39\end{array}$ & $\begin{array}{c}38.7 \\
13.1 \\
26.6 \\
2 \\
19.06\end{array}$ \\
\hline $\begin{array}{l}\text { The main clinical symptoms of COVID - } 19 \text { are fever, fatigue, dry cough } \\
\text { and myalgia? }\end{array}$ & $\begin{array}{c}\text { Yes } \\
\text { No } \\
\text { Don't know }\end{array}$ & $\begin{array}{c}160 \\
11 \\
27\end{array}$ & $\begin{array}{c}80.4 \\
5.5 \\
13.6\end{array}$ \\
\hline $\begin{array}{l}\text { Diarrhoea, headache, redness of eyes and constipation are the symptoms } \\
\text { of COVID } 19 \text { virus infection? }\end{array}$ & $\begin{array}{l}\text { Yes } \\
\text { No } \\
\text { Don't know }\end{array}$ & $\begin{array}{l}68 \\
69 \\
62\end{array}$ & $\begin{array}{l}34.2 \\
34.7 \\
31.2\end{array}$ \\
\hline In which group of people is the disease more dangerous? & $\begin{array}{l}<10 \text { years } \\
>60 \text { years } \\
\text { Pregnant women } \\
15-30 \text { years } \\
30-45 \text { year }\end{array}$ & $\begin{array}{c}20 \\
132 \\
40 \\
7 \\
0\end{array}$ & $\begin{array}{c}10.1 \\
66.3 \\
20.1 \\
3.5 \\
0\end{array}$ \\
\hline Getting pregnant is safe during the Covid 19 pandemic? & $\begin{array}{l}\text { Yes } \\
\text { No } \\
\text { Don't know }\end{array}$ & $\begin{array}{l}36 \\
99 \\
64\end{array}$ & $\begin{array}{l}18.1 \\
49.7 \\
32.2\end{array}$ \\
\hline $\begin{array}{l}\text { There are chances of transmission of corona virus from mother to baby } \\
\text { during pregnancy? }\end{array}$ & $\begin{array}{c}\text { Yes } \\
\text { No } \\
\text { Don't know }\end{array}$ & $\begin{array}{c}103 \\
53 \\
43\end{array}$ & $\begin{array}{l}51.8 \\
26.6 \\
21.6\end{array}$ \\
\hline $\begin{array}{l}\text { Visiting a health care worker for regular antenatal check-up increases the } \\
\text { risk of transmission of corona virus? }\end{array}$ & $\begin{array}{l}\text { Yes } \\
\text { No } \\
\text { Don't know }\end{array}$ & $\begin{array}{l}75 \\
88 \\
36\end{array}$ & $\begin{array}{l}37.7 \\
44.2 \\
18.1\end{array}$ \\
\hline $\begin{array}{l}\text { The risk of infection and complications is increased if I have complications } \\
\text { like diabetes, asthma and anaemia in this pregnancy? }\end{array}$ & $\begin{array}{l}\text { Yes } \\
\text { No } \\
\text { Don't know }\end{array}$ & $\begin{array}{c}123 \\
45 \\
31\end{array}$ & $\begin{array}{l}61.8 \\
22.6 \\
15.6\end{array}$ \\
\hline Which of the following is the treatment for COVID $19 ?$ & $\begin{array}{l}\text { Antibiotics } \\
\text { Vaccines } \\
\text { No treatment } \\
\text { Don't know }\end{array}$ & $\begin{array}{l}67 \\
56 \\
31 \\
44\end{array}$ & $\begin{array}{l}33.7 \\
28.1 \\
15.6 \\
22.1\end{array}$ \\
\hline
\end{tabular}




\begin{tabular}{|c|c|c|c|}
\hline Questions & & Numbers Answered & Percentage \\
\hline \multirow{3}{*}{ Social distancing is necessary during this pandemic as I am pregnant? } & Yes & 197 & 98 \\
\hline & No & 0 & 0 \\
\hline & Don't know & 3 & 2 \\
\hline \multirow{3}{*}{$\begin{array}{c}\text { Changes in my diet and taking additional nutritional supplements helps in } \\
\text { developing immunity against corona virus? }\end{array}$} & Yes & 175 & 87.9 \\
\hline & No & 17 & 8.5 \\
\hline & Don't know & 7 & 3.5 \\
\hline \multirow{3}{*}{$\begin{array}{l}\text { It is better to maintain social distancing with relatives and neighbours who } \\
\text { have history of travel and contact history? }\end{array}$} & Yes & 102 & 51.3 \\
\hline & No & 90 & 45.2 \\
\hline & Don't know & 6 & 3 \\
\hline \multirow{3}{*}{$\begin{array}{l}\text { Anxious about increased chance of getting infected by Covid } 19 \text { to the } \\
\text { mother and baby? }\end{array}$} & Yes & 109 & 54.8 \\
\hline & No & 22 & 11.1 \\
\hline & Don't know & 6 & 33.2 \\
\hline \multirow{3}{*}{$\begin{array}{l}\text { There can be complications in my pregnancy if I am infected with corona } \\
\text { virus? }\end{array}$} & Yes & 147 & 73.9 \\
\hline & No & 25 & 12.6 \\
\hline & Don't know & 27 & 13.6 \\
\hline \multirow{3}{*}{ Testing for COVID 19 is necessary for all pregnant women? } & Yes & 147 & 73.9 \\
\hline & No & 25 & 12.6 \\
\hline & Don't know & 27 & 13.6 \\
\hline \multirow{3}{*}{ Women should avoid getting pregnant during the COVID 19 pandemic? } & Yes & 122 & 61.3 \\
\hline & No & 34 & 17.1 \\
\hline & Don't know & 43 & 21.6 \\
\hline \multirow{3}{*}{$\begin{array}{l}\text { Social distancing is sufficient to control transmission of corona virus } \\
\text { infection? }\end{array}$} & Yes & 155 & 77.9 \\
\hline & No & 30 & 15.1 \\
\hline & Don't know & 13 & 6.5 \\
\hline \multirow{3}{*}{ I think lockdown is essential to bring down transmission of this pandemic? } & Yes & 138 & 69.3 \\
\hline & No & 43 & 21.6 \\
\hline & Don't know & 17 & 8.5 \\
\hline & titude & & \\
\hline
\end{tabular}

\begin{tabular}{|c|c|c|c|}
\hline Questions & & Numbers Answered & Percentage \\
\hline \multirow{3}{*}{ I am maintaining social distance as I am pregnant } & Yes & 154 & 77.4 \\
\hline & No & 19 & 9.5 \\
\hline & Don't know & 23 & 11.6 \\
\hline \multirow{4}{*}{$\begin{array}{l}\text { To prevent spreading the infection of COVID } 19 \text { I am wearing facial mask } \\
\text { Only in public places \& gatherings }\end{array}$} & Most of the time & 160 & 80.4 \\
\hline & Always & 14 & 7 \\
\hline & Never & 23 & 11.6 \\
\hline & Don't know & 2 & 1 \\
\hline \multirow{3}{*}{$\begin{array}{l}\text { I am washing hands frequently and rubbing hands with alcohol-based } \\
\text { sanitizer frequently to prevent covid19 infection }\end{array}$} & Yes & 190 & 95.5 \\
\hline & No & 0 & 0 \\
\hline & Don't know & 9 & 4.5 \\
\hline \multirow{3}{*}{$\begin{array}{l}\text { I am staying indoors most of the time during lockdown and not visiting } \\
\text { public gathering to prevent getting infected by COVID } 19\end{array}$} & Yes & 193 & 97 \\
\hline & No & 3 & 1.5 \\
\hline & Don't know & 2 & 1 \\
\hline \multirow{3}{*}{$\begin{array}{l}\text { Using herbal medicines and traditional supplements is helping me prevent } \\
\text { infection during pregnancy }\end{array}$} & Yes & 115 & 57.8 \\
\hline & No & 10 & 5 \\
\hline & Don't know & 74 & 37.2 \\
\hline \multicolumn{4}{|c|}{ Table 4. Practice } \\
\hline
\end{tabular}

The questions on practices were on proper practice of social distancing, proper hand washing, maintaining social distance and use of herbal medicines and additional nutritional supplements to prevent infection. All antenatal women attending the outpatient department at K S Hegde Hospital, Mangalore who agreed to participate in the study completed the questionnaire.

\section{Measures}

The questionnaire consisted of 4 parts: demographics, knowledge, attitude and practices. A Covid-19 KAP questionnaire was developed. The questionnaire had 25 questions: 11 questions on knowledge, 9 questions on attitude, 5 questions on practices and 7 questions on demographic data. Three general questions on history of travel in recent days, source of information about the latest updates on Covid-19 and co-morbid conditions were asked. Questions were answered on a yes / no basis with additional I don't know option. Open ended questions were asked.

\section{Statistical Analysis}

A score of 1 was attributed to a correct answer and 0 to a wrong answer. The knowledge range was 6 - 9, for attitude 4 -
7 and 2 - 4 for practice. The overall scores of each individual were used to obtain mean scores for KAP. Bloom's cut off was used. Frequencies of correct knowledge answers and various attitude and practices were described. Chi-square test was utilized to compare categorical variables and ratios. Data analysis was conducted with SPSS version 23.0.

\section{RESULTS}

\section{Study Population Characteristics}

A total of 202 pregnant women participated in the study and all the study participants (100\%) were aware of the Covid19 infection pandemic globally. The mean age of the study cohorts was 28 to 32 years, ranged from 18 to 40 years. All the participants were married (100\%). Primigravidas were 70 in number (35.2\%), multiparous with second gravida were $52(26.1 \%)$ and third gravida and more were 80 in number (38.7\%). Patients residing in urban area were 32.2 $\%$ and in rural area were $67.8 \%$. Most of the participants (72.4\%) had some formal education of minimum of secondary schooling. The pregnant women included in the study belonged to all gestational age with most of them belonging to 14 to 28 weeks (46.7\%). None of the women 
had history of travel in recent days during pregnancy. Among 202 women, 144 women $(72.4 \%)$ got the information about Covid-19 through electronic visual media by news and radio and via newspaper by 37 women (18.6\%). Presence of comorbid conditions (pregnancy induced hypertension, gestational diabetes mellitus, asthma and tuberculosis) was seen in $8.5 \%$ of pregnant women.

\section{Knowledge Score Related to Covid-19}

The depth of knowledge of preventive measures against coronavirus infection among the participants is shown in Figure 1. Cough, fever and difficult breathing were most common symptoms known by participants (80.4\%). Among the 202 pregnant women almost more than one third $(34.2$ $\%)$ of the participants knew that diarrhoea, headache, redness of eyes and constipation is a symptom of coronavirus infection. Most of the participants had a knowledge of the most common age group susceptible to the virus (66.4\%) was $>60$ years. Majority of pregnant women (49.9) thought that getting pregnant during the pandemic was not safe. Most of the pregnant women ( $51.8 \%$ ) had opinion that if they are infected during pregnancy with Covid-19 infection then there are chances that the baby will get infected by vertical transmission. The knowledge regarding treatment for the virus was inadequate among majority of the participants.

\section{Attitude Score Related to Covid-19}

Among the pregnant women (98\%) women had good attitude towards the preventive measures against the infection. 197 women among 202 participants knew that social distancing is essential for preventing the infection. Most of the pregnant women (87.9\%) had changes in the diet and were taking additional nutritional supplements to help develop immunity against corona virus. The anxiousness and complications to the baby and the mother was high among the pregnant women (73.9\%). Many participants thought that avoiding pregnancy was safer in this pandemic. Most of the pregnant women wanted testing by reverse transcriptase polymerase chain reaction (RTPCR) during pregnancy for all pregnant women during delivery.

\section{Practice Score Related to Covid-19}

The preventive measures known by participants were washing hands frequently with soap and water or rubbing hands with alcohol-based sanitizers (95.5\%), maintaining at least 1-meter distance between yourself and others (77.7 \%), avoiding touching eyes, nose and mouth with hands (75 \%), covering mouth and nose when coughing or sneezing and wearing face mask in public (80.4\%). Many pregnant women preferred staying indoors during lockdown and not visiting public gatherings to prevent getting infected by Covid-19 (97 \%). Participants had the opinion that using herbal medicines and traditional supplements would help to prevent infection during pregnancy $(57.8 \%)$.

\section{DISCUSSION}

Since the outbreak the pandemic has brought chaos to lives and economics around the world. As of now, India is facing biggest health emergency since the time country has gained independence. ${ }^{15}$ The overall knowledge score was higher among the pregnant women. Multivariate analysis showed confounding factors (education level and occupation) as strong indicator of knowledge regarding Covid-19 which postulates the combination of better access to information and high education level leads to appropriate apprehension and comprehension of information on Covid-19, consequent to better knowledge on Covid-19. Most of the pregnant women had good knowledge about basic symptoms of corona virus such as fever, cough and breathlessness (77\%). They had good knowledge about the mode of spread of infection via respiratory droplets. The basic awareness about the mode of transmission and susceptible age group of more than 60 years was known to many pregnant women (66.3\%). Our study has strong association of knowledge significantly with positive attitude and practice. Through this study it was noted that many pregnant women were anxious about higher chance of infection to the baby by vertical transmission. Most of the women were of the opinion that it was not safe to get pregnant during the pandemic.

Anikwe et al. showed that majority of pregnant women in their third trimester in Nigeria demonstrated good attitude and preventative practices of Covid-19.8 They followed good practising of hand washing, wearing masks, avoiding face touching and quarantining infected people as good practices towards the prevention of Covid-19 infection. In this study $95.5 \%$ of women maintained social distance and practised hand washing and also use of alcohol-based sanitizer.

Yassa et al. focused on Turkish pregnant women in attitude, concerns and knowledge towards Covid-19 from 30 weeks gestation onwards ${ }^{12}$ where Turkey was one of the most affected countries at the time of the study with over 20,000 cases and 425 deaths in April 2020.12 They showed that about $80 \%$ of women felt vulnerable towards the outbreak and $45 \%$ of women were confused or doubtful about the mode of delivery. In the study $50 \%$ of pregnant women were not sure if breast feeding was safe. ${ }^{12}$ These views reflect the vulnerability of pregnant women despite differences in race or culture as pregnant women want the best outcome for themselves and minimize risk of vertical transmission to their baby. Hence it is of paramount importance for clinicians to reflect and counsel on the insecurities and worries of pregnant women towards Covid19.

\section{CONCLUSIONS}

Majority of pregnant women demonstrated good knowledge, positive attitude and good practice regarding Covid-19 pandemic. The main concern of pregnant women was the vertical transmission of the infection to the baby during pregnancy. Proper counseling by the health care workers and supportive care by multidimensional approach will help decrease the consequences of the pandemic in all aspects. Increasing health education program regarding the pandemic 
via different mass media and social media with the coordinated and combined efforts of government authorities and all individuals will be needed to battle the consequences of the pandemic. This will help address the effect of Covid-19 on pregnancy and pregnancy outcome.

Data sharing statement provided by the authors is available with the full text of this article at jemds.com.

Financial or other competing interests: None.

Disclosure forms provided by the authors are available with the full text of this article at jemds.com.

\section{REFERENCES}

[1] Coronavirus Disease (COVID-19). Q \& A 2020. (Updated on 17th April 2020: Cited on 2020, 28 April) https://www.who.int/news-room/q-a-detail/q-acoronaviruses

[2] Coronavirus disease (COVID-19) advice for the public: mythbusters. WHO 2020. [updated 2020 April 19, cited 2020 Apr 29th]. https://www.who.int/emergencies/diseases/novelcoronavirus-2019/advice-for public/myth-busters

[3] WHO. Infection prevention and control of epidemic-and pandemic-prone acute respiratory infections in health care. Geneva: World Health Organisation 2014. [2014; cited $2020 \quad$ Apr 19$]$. https://www.ncbi.nlm.nih.gov/books/NBK214359

[4] Bootsma MC, Ferguson NM. The effect of public health measures on the 1918 influenza pandemic in U.S. cities. Proc Natl Acad Sci U S A 2007; 104(18):7588-93.

[5] Tomar BS, Singh P, Suman S, et al. Indian community's knowledge, attitude \& practice towards COVID-19. medRxiv 2020.

[6] Zhong BL, Luo W, Li HM, et al. Knowledge, attitudes and practices towards COVID-19 among Chinese residents during the rapid rise period of the COVID-19 outbreak: a quick online cross-sectional survey. Int J Biol Sci 2020;16(10):1745-52.

[7] WHO. Coronavirus infections: disease outbreak news WHO 2020. [Updated on 25th July: cited on $2020 \mathrm{Apr}$ 29]. https://www.who.int/emergencies/diseases/novelcoronavirus-2019

[8] Anikwe CC, Ogah CO, Anikwe IH, et al. Coronavirus disease 2019: knowledge, attitude and practice of pregnant women in a tertiary hospital in Abakaliki, Southeast Nigeria. Int J Gynaecol Obstet 2020;151(2):197-202.

[9] CDC. Clinical questions about covid-19: questions and answers. Centers for Disease Control and Prevention 2021. (Updated on $16^{\text {th }}$ April 2020; cited on 2020, 20 April) https://www.cdc.gov/coronavirus/2019ncov/hcp/faq.html

[10] Erfani A, Shahriarirad R, Ranjbar K, et al. Knowledge, attitude and practice toward the novel coronavirus (COVID-19) outbreak: a population-based survey in Iran. Bull World Health Organ. E-pub: 2020.

[11] Corbett GA, Milne SJ, Hehir MP, et al. Health anxiety and behavioural changes of pregnant women during the COVID-19 pandemic. Eur J Obstet Gynecol Reprod Biol 2020;249:96-7.

[12] Zaigham M, Andersson 0. Maternal and perinatal outcomes with COVID-19: a systematic review of 108 pregnancies. Acta Obstet Gynecol Scand 2020;99(7):8239.

[13] Yassa M, Birol P, Yirmibes C, et al. Near-term pregnant women's attitude toward, concern about and knowledge of the COVID-19 pandemic. J Matern Fetal Neonatal Med 2020;33(22):3827-34.

[14] Khalil A, Kalafat E, Benlioglu C, et al. SARS-CoV-2 infection in pregnancy: a systematic review and metaanalysis of clinical features and pregnancy outcomes. E Clinical Medicine 2020;25:100446.

[15] Ministry of Health and Family Welfare. COVID-19 India (Updated on 29th Apr 2020: cited on 2020 Apr 29th). https://www.mohfw.gov.in/ 